\title{
Enzymological and Immunological Properties of Pectin Lyases from Bacteriocinogenic Strains of Erwinia carotovora
}

\author{
Yoshifumi IтoH, * Jun Sugiura, Kazuo IzaKi \\ and Hajime TAKAHASHI** \\ Department of Agricultural Chemistry, Faculty of Agriculture, \\ Tohoku University, Sendai 980, Japan
}

Received June 30, 1981

\begin{abstract}
Pectin lyases of four bacteriocinogenic Erwinia carotovora strains, Er, Ar, Ar13 and 6083, were purified to near homogeneity from cultures treated with mitomycin C. Pectin lyases from these strains had similar molecular weights of around 28,000 , and their optimal $\mathrm{pH}$ for reaction was about 8.0. All these enzymes cleaved a highly methylesterified polygalacturonic acid $(90 \%$ esterified) well, but with pectin $(64 \%$ esterified) they showed reduced activities. They did not attack polygalacturonic acid which was not esterified. In contrast to these similarities, the isoelectric points of the enzymes were slightly different from each other, ranging between $\mathrm{p} I 9.55$ and 9.62 , and suggests that these enzymes were not identical protein molecules. Antiserum against the pectin lyase of strain Er similarly inactivated the pectin lyases of the other strains, as well as the pectin lyase of strain Er. No immunoprecipitate line was formed between the antiserum against pectin lyase of strain Er and polygalacturonic acid (pectate) lyase of this strain or between antiserum against pectate lyase of strain $\mathrm{Er}$ and pectin lyases of the four strains. Antiserum against carotovoricin from strain Er neutralized carotovoricins from strains Er, Ar, Ar13 and 6083 to a similar extent. These results imply that these pectin lyases share a common genetic background and that these carotovoricins might be derived from the same source.
\end{abstract}

Pectolytic enzymes of microorganisms have been considered to be responsible for diseases of many plant tissues referred to as maceration or rotting. ${ }^{1)}$ Chatterjee and Starr $^{2)}$ clearly demonstrated that polygalacturonic acid lyase (trans-eliminase) plays an essential role in causing plant-tissue maceration in Erwinia chrysanthemi by a genetical approach. The role of polygalacturonic acid (pectate) lyase in plant-tissue maceration and regulation of the enzyme were reviewed by Chatterjee and Starr. ${ }^{3)}$

Tomizawa et $a l .{ }^{4)}$ reported that pectolytic enzyme formation in Erwinia carotovora $\mathrm{Er}$ (formerly termed E. aroideae Er) was markedly stimulated when the cells were treated with nalidixic acid, mitomycin $\mathrm{C}$, bleomycin or $\mathrm{UV}$

* Present address: The Department of Bacteriology, Shinshu University School of Medicine, Matsumoto 390, Japan.

** Author to whom reprint requests should be addressed. light irradiation. The pectolytic enzyme formed by E. carotovora $\mathrm{Er}$ treated with nalidixic acid has been purified and characterized as a pectin lyase, ${ }^{5)}$ while this strain produces pectate lyase when polygalacturonic acid or pectin was added to the cultural medium as an inducer. ${ }^{6)}$ Tomizawa et al.$^{4)}$ also reported that $E$. carotovora Er formed a phage tail-like substance as well as pectin lyase accompanied by cell lysis in the presence of the drugs or after exposure to UV light. The phage tail-like substance was identified as a bacteriocin, $\left.{ }^{6}\right)$ named carotovoricin, and purified. ${ }^{7)}$ In a previous report, ${ }^{8)}$ Itoh et al. demonstrated that four strains of $E$. carotovora among five bacteriocinogenic strains tested produced pectin lyases as well as carotovoricins when the strains were treated with nalidixic acid, mitomycin $\mathrm{C}$ or UV light irradiation. We purified pectin lyases produced by four bacteriocinogenic strains as nearly homogeneous proteins, and we report here some enzymatic and 
immunological properties of the pectin lyases. We also report on the immunological relationship between carotovoricins.

\section{MATERIALS AND METHODS}

Bacterial strains. The following four bacteriocinogenic strains of E. carotovora, from which pectin lyases and carotovoricins were prepared, were used: E. carotovora $\mathrm{Er}$ ASM 6082 and ASM 6083 were from the collections of our laboratory. E. carotovora $\mathrm{Ar}$ and $\mathrm{Ar} 13$ were kindly donated by Prof. H. Tsuyama (Faculty of Agriculture, Iwate Univ., Morioka). Strains of E. carotovora sensitive to carotovoricins from the four bacteriocinogenic strains were described previously. ${ }^{8)}$ E. carotovora $645 \mathrm{Ar}$, an indicator strain sensitive to all carotovoricins from the four strains, was also supplied by Professor H. Tsuyama.

Preparation of substrates. Pectin and pectic acid (Wako Pure Chemicals Industry, Ltd., Osaka) were washed three times with $70 \%(\mathrm{v} / \mathrm{v})$ ethanol to remove soluble carbohydrates. A highly methoxylated polygacturonic acid was prepared by the method of Manabe. ${ }^{9)}$ The degree of esterification of the substrates was determined according to the method of Hirota. ${ }^{10)}$

Assay of pectin lyase and carotovoricin. Pectin lyase (EC: 4.2.2.10) activity was measured as described previously. ${ }^{8)}$ The titer of carotovoricin was determined by a spot test ${ }^{7)}$ with successive 2- or 10-fold dilution of the solution to be titrated using E. carotovora $645 \mathrm{Ar}$ as the indicator strain.

Purification of pectate lyase, pectin lyase and carotovoricin Er. Pectate lyase (EC: 4.2.2.2) of E. carotovora Er was purified as described by Kamimiya et al. ${ }^{11)}$ Pectin lyases of the following strains were purified as described by Kamimiya et al. $^{5)}$ with a slight modification. Unless otherwise noted, the organisms were grown in M9glucose-casein acid hydrolysate medium ${ }^{7)}$ at $30^{\circ} \mathrm{C}$ with shaking. To one liter of log-phase cultures of E. carotovora $\mathrm{Er}$ and $\mathrm{Ar} 13$, mitomycin $\mathrm{C}$ (Kyowa Hakko Kogyo Co., Ltd., Tokyo) was added to final concentrations of $0.4 \mu \mathrm{g} / \mathrm{ml}$ and $1 \mu \mathrm{g} / \mathrm{ml}$, respectively. The cultures were further incubated for an additional $6 \mathrm{hr}$. In the cases of E. carotovora Ar and 6083, the log-phase cells in each one liter culture were exposed to mitomycin $\mathrm{C}$ for $15 \mathrm{~min}, 1 \mu \mathrm{g} / \mathrm{ml}$ for strain Ar and $5 \mu \mathrm{g} / \mathrm{ml}$ for strain 6083 , and the cells were then collected by centrifugation and resuspended in the initial volume of prewarmed medium. These cultures were further incubated for an additional $6 \mathrm{hr}$. After incubation, cells and cell debris were removed by centrifugation at $10,000 \times g$ at $4^{\circ} \mathrm{C}$ for $10 \mathrm{~min}$ and the clear supernatants obtained were used as crude enzyme and carotovoricin preparations. The crude preparations were concentrated to $100 \mathrm{ml}$ with a flash evaporator. After removing insoluble materials by centrifugation at $10,000 \times g$ for $10 \mathrm{~min}$, the concentrated fluids were centrifuged at $60,000 \times g$ for $90 \mathrm{~min}$ at $10^{\circ} \mathrm{C}$. Precipitates containing carotovoricin activity were re-

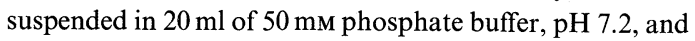
stocked in $50 \%$ glycerol at $-20^{\circ} \mathrm{C}$ until use. While the supernatants were dialyzed against 2 liters of distilled water at room temperature for $12 \mathrm{hr}$ and then against 2 liters of distilled water at $4^{\circ} \mathrm{C}$ for $12 \mathrm{hr}$, and finally against 2 liters of $10 \mathrm{~mm}$ phosphate buffer, $\mathrm{pH} 7.2$. The dialyzed samples were applied on a DEAE-cellulose column (10 $\mathrm{cm} \times 1.5 \mathrm{~cm}$ ). Pectin lyases were not adsorbed to this column. The fractions that passed through the column were then applied on a CM-cellulose column $(18 \mathrm{~cm} \times 1.4$ $\mathrm{cm}$ ), and the column was washed with $50 \mathrm{ml}$ of $10 \mathrm{~mm}$ phosphate buffer, $\mathrm{pH}$ 7.2. Elution was done with a linear gradient of $\mathrm{NaCl}$ from zero to $0.5 \mathrm{M}$ in $10 \mathrm{~mm}$ phosphate buffer, $\mathrm{pH} 7.2(500 \mathrm{ml})$. The fractions $(10 \mathrm{ml})$ containing enzyme activity were pooled and concentrated to $1.0 \mathrm{ml}$ by ultrafiltration using a G-10T membrane (Bio Engineering Co., Ltd., Tokyo). The concentrated samples were subjected to gel filtration on a Sephadex G-75 column (90 $\mathrm{cm} \times 1.5 \mathrm{~cm}$ ). Elution of the Sephadex G-75 column was done with $50 \mathrm{~mm}$ phosphate buffer, $\mathrm{pH} 7.2$.

Carotovoricin Er was purified from the culture (5 liters) of E. carotovora $\mathrm{Er}$ treated with mitomycin $\mathrm{C}$ as described previously. ${ }^{7)}$

Preparation of antisera against pectate and pectin lyases from E. carotovora Er, and carotovoricin Er. Freund's complete adjuvant (Iatron Laboratory, Tokyo) was emulsified with an equal volume of a solution of the purified pectate lyase $(1 \mathrm{mg} / 0.2 \mathrm{ml})$, pectin lyase $(1 \mathrm{mg} / 0.2 \mathrm{ml})$, or carotovoricin $\operatorname{Er}(0.2 \mathrm{mg} / 0.2 \mathrm{ml})$. These antigens were prepared in phosphate buffered saline, $\mathrm{pH}$ 7.2. Adult guinea pigs were injected subcutaneously at several sites on the back with $0.4 \mathrm{ml}$ of the emulsions. Injections were repeated 3 times at 2 week intervals. Ten days after the last injection, blood was collected from the hearts with syringes. After the blood was allowed to clot, the sera were centrifuged at $35,000 \times g$ for $1 \mathrm{hr}$ at $4^{\circ} \mathrm{C}$, and the resultant antisera were stored at $-80^{\circ} \mathrm{C}$ or at $4^{\circ} \mathrm{C}$ with $0.1 \%(\mathrm{w} / \mathrm{v})$ of $\mathrm{NaN}_{3}$.

Gel electrophoresis. Sodium dodecyl sulfate (SDS) polyacrylamide gel electrophoresis was performed according to the method of $\mathrm{Laemmli}^{12)}$ using $10 \%$ polyacrylamide gel. The electrophorized gel was stained with $0.025 \%(\mathrm{w} / \mathrm{v})$ Coomassie brilliant blue. Ampholine isoelectric focusing gel electrophoresis was carried out according to the protocol of the manufacturer (LKB, Broma, Sweden). The $\mathrm{pH}$ range of Ampholine was $9 \sim 11$. Gel staining was done according to the method of Vesterberg. ${ }^{13)}$

Double immunodiffusion. Ouchterlony double immunodiffusion $^{14)}$ was performed on $1 \%$ agarose in phosphate buffered saline containing $0.1 \%(\mathrm{w} / \mathrm{v})$ of $\mathrm{NaN}_{3}$. Precipitate 
lines formed were stained with Coomassie brilliant blue.

\section{RESULTS}

\section{Purification of pectin lyases}

Pectin lyase activities in the culture fluids of E. carotovora Er and Ar 13 treated with mitomycin $\mathrm{C}$ were 24.2 units $/ \mathrm{ml}$ and 20.0 units $/ \mathrm{ml}$, respectively. When E. carotovora Ar and 6083 were treated with mitomycin $\mathrm{C}$, pectin lyase activities were also found in the culture fluids although the activities were lower. ${ }^{8}$ However, when these cells were grown in the medium in the absence of the drug after a brief exposure to the drug, formation of pectin lyase increased $3 \sim 5$ fold. Pectin lyase activities in the culture fluids of E. carotovora Ar and 6083 were 27.5 units $/ \mathrm{ml}$ and 15.8 units $/ \mathrm{ml}$, respectively. Pectin lyases of E. carotovora $\mathrm{Ar} 13, \mathrm{Ar}$ and 6083 showed essentially the same behavior on CM-cellulose and Sephadex G-75 column chromatography like the enzyme of E. carotovora Er which was purified previously. ${ }^{5}$ Pectin lyases of the four strains were eluted from the CM-cellulose column with $0.1 \mathrm{M}$ $\mathrm{NaCl}$ and from the Sephadex G-75 column with $120 \mathrm{ml}$ of the elution buffer. This elution volume corresponded to a molecular weight of around 32,000. Through these procedures, four enzymes were purified about 70 -fold with yields of $40 \sim 50 \%$. The purified enzyme preparations, fractions from Sephadex G-75 column chromatography, were subjected to SDS polyacrylamide gel and Ampholine isoelectric focusing gel electrophoresis. As shown in Fig. 1, the purified enzymes of strains Er, Ar 13 and Ar were almost homogeneous but the purified enzyme of strain 6083 still contained another minor protein with a molecular weight of 26,000 . These purified enzymes were shown to be also homogeneous on Ampholine isoelectric focusing gel electrophoresis as shown in Fig. 2.

\section{Properties of pectin lyases}

Molecular weights of pectin lyases from the four strains were around 28,000 which were determined by SDS polyacrylamide gel electrophoresis (Fig. 1). However, their isoelectric

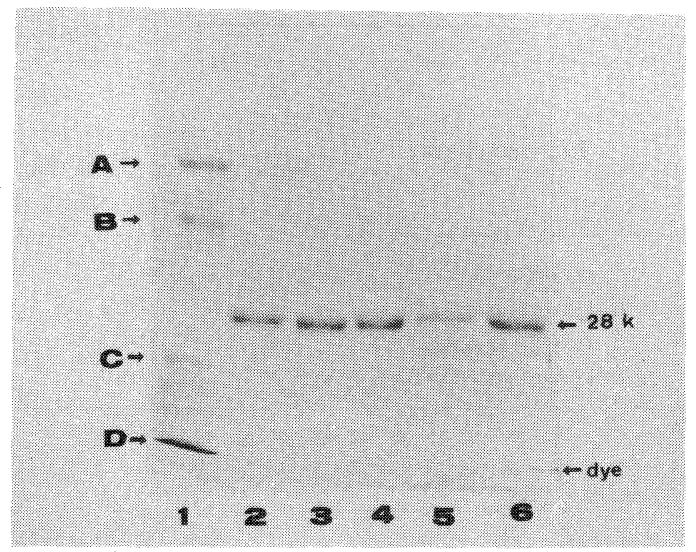

FIG. 1. SDS Polyacrylamide Gel Electrophoresis of Purified Pectin Lyases.

Molecular weight standards (1): A, bovine serum albumin $(68,000)$; B, ovalbumin $(48,000)$; C, catalase $(25,000)$; D, cytochrome $c(12,500)$. Pectin lyases of strains $\operatorname{Er}(2), \operatorname{Ar} 13$ (3), Ar (4) and 6083 (5). A mixture of pectin lyases from the four strains (6).

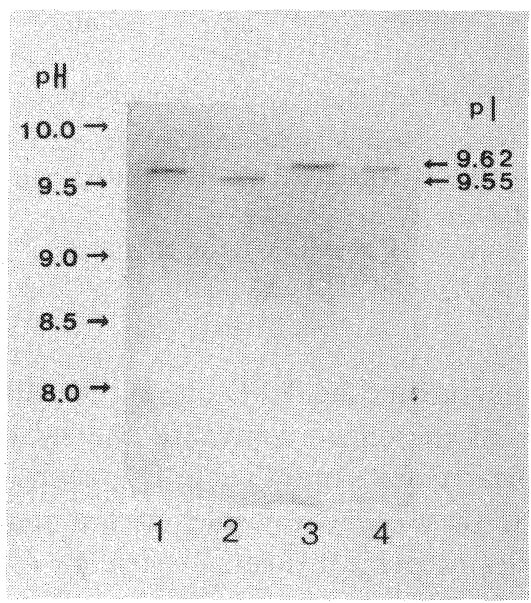

FIG. 2. Ampholine Isoelectric Focusing Gel Electrophoresis of Purified Pectin Lyases.

Pectin lyases from strains Er (1), Ar13 (2), Ar (3) and 6083 (4).

points $(\mathrm{p} I)$ were slightly different from each other. pIs of the enzymes from strains $\mathrm{Er}, \mathrm{Ar}$ 13, Ar and 6083 were 9.58, 9.55, 9.62 and 9.60, respectively. Activities of the enzymes were completely dependent on the extent of methylation at the carboxyl group of the substrate. All enzymes attacked a highly methoxylated polygalacturonic acid well and pectin to a lesser extent, but they could hardly act on 
Table I. Substrate Specificity of Pectin Lyases

\begin{tabular}{lccc}
\hline \multirow{2}{*}{ Enzyme source } & \multicolumn{3}{c}{ Pectin lyase activity $\left(10^{3}\right.$ units/mg protein $)$} \\
\cline { 2 - 4 } & $\begin{array}{c}\text { Methoxylated polygalacturonic } \\
\text { acid }(90 \% \text { esterified })\end{array}$ & $\begin{array}{c}\text { Pectin } \\
(64 \% \text { esterified })\end{array}$ & $\begin{array}{c}\text { Polygalacturonic acid } \\
(0 \% \text { esterified })\end{array}$ \\
\hline E. carotovora $\mathrm{Er}$ & 13.7 & 4.6 & 0.1 \\
E. carotovora $\mathrm{Ar} 13$ & 14.3 & 6.0 & 0.5 \\
E. carotovora $\mathrm{Ar}$ & 14.2 & 4.8 & 0.2 \\
E. carotovora 6083 & 16.0 & 4.3 & 0.5 \\
\hline
\end{tabular}

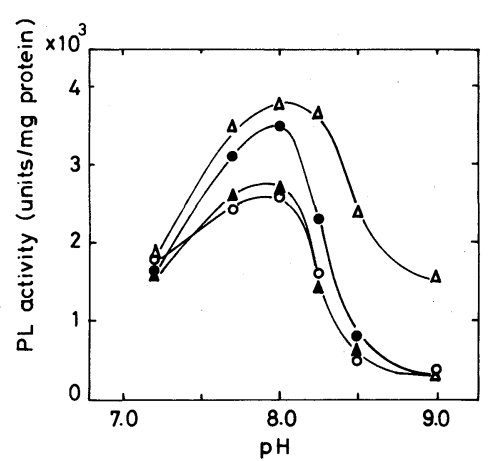

FIG. 3. Pectin Lyase Activities as a Function of $\mathrm{pH}$.

Pectin lyase activities were assayed in $0.05 \mathrm{M}$ Tris(hydroxymethyl)-aminomethane- $\mathrm{HCl}$ buffer with a $\mathrm{pH}$ range of $7.2 \sim 9.0$.

Pectin lyase (PL) activities from strains $\mathrm{Er}(\mathrm{O})$, $\mathrm{Ar}$ $(\triangle), \operatorname{Ar} 13(\triangle)$ and $6083(\Delta)$.

polygalacturonic acid (Table I). Specific activities of the enzymes toward the substrates were nearly the same (Table I). As shown in Fig. 3, these enzymes showed the maximal activities at $\mathrm{pH}$ 8.0. Pectate lyase of E. carotovora $\mathrm{Er}$ has been reported to be activated by $\mathrm{Ca}^{2+}$, and inhibited by ethylenediaminetetraacetic acid (EDTA). ${ }^{11)}$ Neither $\mathrm{Ca}^{2+}$ nor EDTA affected the activities of pectin lyases from the four strains.

\section{Immunological properties of pectin lyases}

Immunological relations among pectin lyases from the four strains and between the pectin and pectate lyases of strain Er were examined. Antiserum against pectin lyase of strain Er cross-reacted with pectin lyases from the other strains as well as pectin lyase but not with pectate lyase from this strain. Similarly, antiserum against pectate lyase of strain Er did

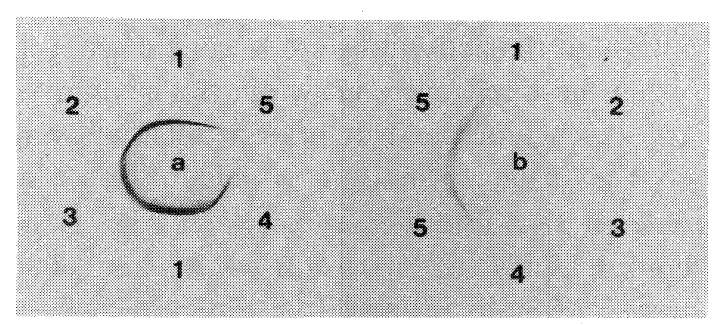

FIG. 4. Double Immunodiffusion Profiles.

a: Antiserum against pectin lyase. b: Antiserum against pectate lyase. 1, pectin lyase from strain Er; 2, pectin lyase from strain Ar; 3, pectin lyase from strain Ar13; 4, pectin lyase from strain $6083 ; 5$, pectate lyase from strain Er.

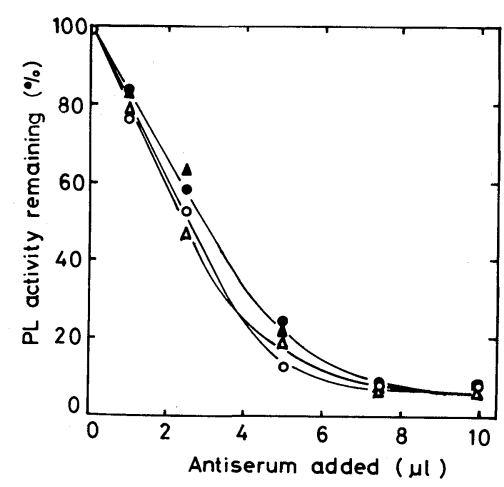

FIG. 5. Inactivation of Pectin Lyases by Antiserum against Pectin Lyase from E. carotovora Er.

The mixtures $(0.2 \mathrm{ml})$ contained $2 \mu \mathrm{g}$ of pectin lyase and the indicated amounts of antiserum in phosphate buffered saline. They were incubated at $30^{\circ} \mathrm{C}$ for $20 \mathrm{~min}$, and then kept at $4^{\circ} \mathrm{C}$ overnight. The enzyme activities of the mixtures were measured. The activity of each enzyme incubated with the control serum was taken as $100 \%$. Pectin lyase (PL) activities from strains $\operatorname{Er}(\bigcirc), \operatorname{Ar}(\mathbf{O})$, $\operatorname{Ar} 13(\triangle)$ and $6083(\mathbf{\Delta})$.

not cross-react with pectin lyases from all the strains (Fig. 4). As shown in Fig. 5, all pectin lyases from the four strains were inactivated in 
Table II. Inactivation of Carotovoricins by Antiserum against Carotovoricin Er

\begin{tabular}{|c|c|c|c|c|c|c|c|}
\hline \multirow{3}{*}{ Carotovoricins } & \multirow{3}{*}{ PBS } & \multicolumn{6}{|c|}{ Carotovoricin activity remaining (units $/ \mathrm{ml}$ ) } \\
\hline & & \multirow{2}{*}{$\frac{\text { Control serum }}{10^{\circ}}$} & \multicolumn{5}{|c|}{ Antiserum } \\
\hline & & & $10^{0}$ & $10^{-1}$ & $10^{-4}$ & $10^{-5}$ & $10^{-6}$ \\
\hline Carotovoricin Er & 10 & 10 & 0 & 0 & 0 & 1 & 10 \\
\hline Carotovoricin Ar13 & 10 & 10 & 0 & 0 & 0 & 1 & 10 \\
\hline Carotovoricin $\mathrm{Ar}$ & 10 & 10 & 0 & 0 & 0 & 4 & 10 \\
\hline Carotovoricin 6083 & 10 & 10 & 0 & 0 & 0 & 4 & 10 \\
\hline
\end{tabular}

Solutions of carotovoricins ( 20 units $/ \mathrm{ml}$, in $50 \mu \mathrm{l}$ of $\mathrm{M} 9$ buffer) were mixed with the same volume of phosphate buffered saline (PBS), control serum or antiserum at each step of successive 10-fold dilution with PBS. They were incubated at $30^{\circ} \mathrm{C}$ for $20 \mathrm{~min}$. Carotovoricin activities of these mixtures were assayed.

a similar manner by the antiserum against pectin lyase of strain Er. These results indicate that these pectin lyases have common antigenic properties and there is no immunological relation between these pectin lyases and the pectate lyase.

\section{Immunological relation of carotovoricins}

As reported previously, ${ }^{7,8)}$ E. carotovora $\mathrm{Er}$, Ar, Ar 13 and 6083 are bacteriocinogenic strains. Carotovoricins of strains Er, Ar, Ar 13 and 6083 are designated tentatively as carotovoricins Er, Ar, Ar 13 and 6083, respectively. These carotovoricins are high molecular weight bacteriocins with a phage tail-like structure even though their activity spectra are different from each other. ${ }^{8)}$ To evaluate the immunological relation of these carotovoricins, the sensitivity of these carotovoricins to antiserum against carotovoricin Er was examined. All carotovoricins were similarly inactivated by similar amounts of antiserum against carotovoricin Er, suggesting a close immunological relation among these carotovoricins (Table II).

\section{DISCUSSION}

It has been reported that Erwinia carotovora produces various enzymes acting on pectic substances. Pectolytic enzymes of E. carotovora so far reported include pectinesterase, ${ }^{15}$ ) polygalacturonase, ${ }^{16)}$ polygalacturonic acid (pectate) lyase, ${ }^{17,18)}$ and oligogalacturonide lyase. ${ }^{19)}$ To our knowledge, however, there is no report on a pectin lyase of $E$. carotovora produced during cell growth. Kamimiya et $a l .{ }^{11)}$ reported that the major pectolytic enzyme of E. carotovora Er, a bacteriocinogenic strain, was pectate lyase which was formed when this organism was grown in the presence of pectin or polygalacturonic acid as an inducer. This strain also produced a bacteriocin, carotovoricin Er, as well as pectin lyase when it was treated with nalidixic acid, mitomycin $\mathrm{C}$ or UV light. ${ }^{8)}$ Production of pectin lyase in $E$. carotovora was also found in the other bacteriocinogenic strains ${ }^{8)}$ which produced carotovoricins with different activity spectra indicating an intimate relationship between bacteriocinogenicity and ability to produce pectin lyase. In this work, we demonstrated that purified pectin lyases from four strains had the same molecular weight of around 28,000, and showed essentially the same enzymological properties such as substrate specificity, specific activity and optimal $\mathrm{pH}$. We can, however, conclude that these enzymes are not identical protein molecules because their $\mathrm{p} I$ values were slightly different from each other, ranging between $\mathrm{p} I 9.55$ and 9.62 (Fig. 2). As shown in Figs. 4 and 5, the pectin lyases revealed common antigenic properties suggesting they are derived from the same origin.

Carotovoricins produced by strains Er, Ar, Ar 13 and 6083 have almost the same structure consisting of a contractile sheath of about $200 \AA$ in diameter and $1650 \sim 1800 \AA$ in length 
around a core which is about $80 \AA$ in diameter and $1650 \sim 1800 \AA$ in length. ${ }^{7,8)}$ Although they could not be distinguished by morphological observation, it is clear that they are different bacteriocins because they act on different indicator strains. ${ }^{8}$ ) In addition to the morphological resemblance, these carotovoricins were inactivated similarly by antiserum against carotovoricin Er (Table II) implying their origin might be the same. It has been suggested that high molecular weight bacteriocins having a phage tail-like structure are a kind of defective bacteriophage, ${ }^{20,21)}$ in other words, such bacteriocins might be derived from bacteriophages. We postulate that a gene for pectin lyase might be located within or adjacent to a genome of the bacteriocin, and a repressor, which prevents syntheses of bacteriocin and pectin lyase, would be inactivated to allow syntheses of the enzyme and bacteriocin on exposure of the cells to the inducing agents. It seems also possible that a bacteriophage, probably a lysogenic phage, has carried a gene for pectin lyase from a foreign bacterium into $E$. carotovora and the bacteriophage has become defective due to some unknown reason. However, the possible origin of the pectin lyases in E. carotovora is not known at present. No immunological cross-reaction was observed between pectate lyase and antiserum against pectin lyase or between pectin lyases and antiserum against pectate lyase (Fig. 4). These results indicate that there might be no relation between pectin lyase and pectate lyase with respect to the origin. Pectin lyase has been reported in fungi such as Aspergillus fonsecaeus, ${ }^{22)}$ Penicillium digitatum, ${ }^{23)}$ Penicillium italicum, $^{23)}$ Sclerotinia fructigena ${ }^{24)}$ and Fusarium solani ${ }^{25)}$ and in bacteria, Pseudomonas marginalis. ${ }^{26)}$ Among these pectin lyases, the pectin lyase of Pseudomonas marginalis purified by Ohuchi and Tominaga $^{26)}$ showed similar properties to those of pectin lyase from $E$. carotovora. However, no immunological cross-reaction was observed between pectin lyase from $P$. marginalis and antiserum against pectin lyase from E. carotovora $\operatorname{Er}$ (J. Sugiura, unpublished results).

Acknowledgments. We are grateful to Professor Hiroyuki Tsuyama for providing bacterial strains. We also thank Dr. Hideyuki Takahashi of the National Institute of Animal Health and Dr. Masataka Nakamura of the National Institute of Genetics for their useful advice for immunological studies.

\section{REFERENCES}

1) R. C. Codner, J. Appl. Bacteriol., 34, 147 (1971).

2) A. K. Chatterjee and M. P. Starr, J. Bacteriol., 132, 862 (1977).

3) A. K. Chatterjee and M. P. Starr, Ann. Rev. Microbiol., 34, 645 (1980).

4) H. Tomizawa and H. Takahashi, Agric. Biol. Chem., 35, 191 (1971).

5) S. Kamimiya, T. Nishiya, K. Izaki and $H$. Takahashi, Agric. Biol. Chem., 38, 1071 (1974).

6) S. Kamimiya, K. Izaki and H. Takahashi, Agric. Biol. Chem., 41, 911 (1977).

7) Y. Itoh, K. Izaki and H. Takahashi, J. Gen. Appl. Microbiol., 24, 27 (1978).

8) Y. Itoh, K. Izaki and H. Takahashi, Agric. Biol. Chem., 44, 1135 (1980).

9) M. Manabe, Nippon Nôgeikagaku Kaishi, 45, 195 (1971).

10) I. Hirota, J. Chem. Soc. Jpn., Ind. Chem. Sec., 63, 2194 (1966).

11) S. Kamimiya, Y. Itoh, K. Izaki and H. Takahashi, Agric. Biol. Chem., 41, 975 (1977).

12) U. K. Laemmli, Nature, 227, 680 (1970).

13) O. Vesterberg, Biochim. Biophys. Acta, 257, 11 (1972).

14) Ö. Ouchterlony and L. Å. Nilsson, "Handbook of Experimental Immunology," ed. by D. M. Weir, Blackwell Scientific Publications, Oxford, 1973, Chapter 19.

15) G. Ashwell, A. J. Wahba and J. Hickman, Biochim. Biophys. Acta, 30, 186 (1958).

16) S. Nasuno and M. P. Starr, J. Biol. Chem., 241, 5298 (1966).

17) F. Moran, S. Nasuno and M. P. Starr, Arch. Biochem. Biophys., 123, 298 (1968).

18) M. P. Starr and F. Moran, Science, 135, 920 (1962).

19) F. Moran, S. Nasuno and M. P. Starr, Arch. Biochem. Biophys., 125, 734 (1968).

20) P. Reeves, "The Bacteriocins: Molecular Biology, Biochemistry, and Biophysics," Vol. 11, SpringerVerlag, New York, 1972, p. 17 and p. 83.

21) D. E. Bradley, Bacteriol. Rev., 31, 230 (1967).

22) R. D. Edstrom and H. J. Phaff, J. Biol. Chem., 239, 2403 (1964).

23) D. A. Bush and R. C. Codner, Phytochemistry, 9, 87 (1970). 
24) R. J. W. Byrde and A. H. Fielding, J. Gen. 26) A. Ohuchi and T. Tominaga, Ann. Phytopath. Soc. Microbiol., 52, 287 (1968). Jpn., 40, 22 (1974).

25) D. F. Bateman, Phytopathology, 56, 238 (1966). 